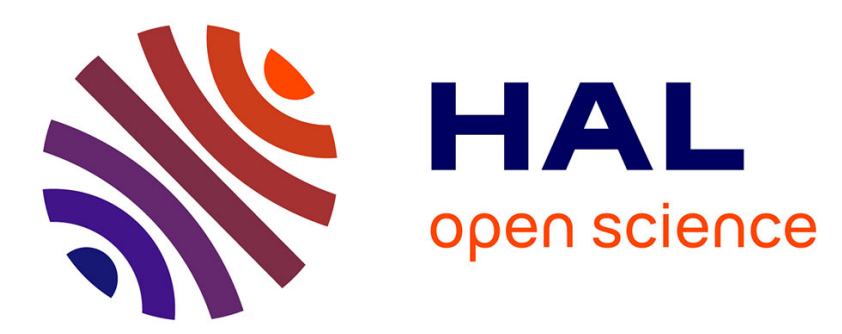

\title{
May the pro-poor impacts of trade liberalisation vanish because of imperfect information?
}

Jean-Marc Boussard, Françoise Gérard, Marie-Gabrielle Piketty, Ane-Katrine Christensen, Tancrède Voituriez

\section{- To cite this version:}

Jean-Marc Boussard, Françoise Gérard, Marie-Gabrielle Piketty, Ane-Katrine Christensen, Tancrède Voituriez. May the pro-poor impacts of trade liberalisation vanish because of imperfect information?. Agricultural Economics, 2004, 31 (2-3), pp.297-305. 10.1111/j.1574-0862.2004.tb00266.x . hal-02678981

\section{HAL Id: hal-02678981 \\ https://hal.inrae.fr/hal-02678981}

Submitted on 31 May 2020

HAL is a multi-disciplinary open access archive for the deposit and dissemination of scientific research documents, whether they are published or not. The documents may come from teaching and research institutions in France or abroad, or from public or private research centers.
L'archive ouverte pluridisciplinaire HAL, est destinée au dépôt et à la diffusion de documents scientifiques de niveau recherche, publiés ou non, émanant des établissements d'enseignement et de recherche français ou étrangers, des laboratoires publics ou privés. 


\title{
May the pro- poor impacts of trade liberalization vanish because of imperfect information?
}

\author{
by:
}

\author{
J.M. Boussard (INRA, France) boussard@,ivry.inra.fr \\ F. Gérard (CIRAD, France), francoise.gerard $@$ cirad.fr \\ M.G. Piketty (Sao-Paolo University/CIRAD, Brazil), marie-gabrielle.piketty@,cirad.fr \\ A.K Christensen (OECD, France), Ane-Katrine.CHRISTENSEN@,oecd.org \\ T. Voituriez (CIRAD, France) tancrede.voituriez@,cirad.fr
}

\begin{abstract}
In this paper, we try to evaluate changes in welfare gains and their distribution due to trade liberalization when imperfect information is considered. The results of two versions of a computable general equilibrium (CGE) model, using the GTAP database and representing goods as well as capital flows, are compared. In the first version, a standard world CGE approach is followed. In the second version we include risk aversion, imperfect information and production lag in the agricultural sector. After a brief description of the two versions, changes in welfare, represented by the income of two types of household (middle-low and middle-high) in three regions (Europe, United States, Rest of the World) after agricultural trade liberalization are presented. Theoretical and political consequences of the results are discussed.
\end{abstract}

Key words: Agricultural trade liberalization, world CGE model, equity, imperfect information, price instability

JEL: C68- Q17

\footnotetext{
${ }^{1}$ This paper is based on research partially funded by the French Ministry of Agriculture and Pluriagri The views expressed here are the sole responsibility of authors, and do not necessarily reflect those of the funding organizations.
} 


\section{Introduction}

The global welfare impact of trade liberalization, including the agricultural sector (Hertel et al., 1999, Hertel and Martin, 2000, Anderson, 2002) stands at the forefront of trade economists' preoccupations. The development of a generic computable general equilibrium (CGE) model (Hertel et al., 1997) and large expected spillovers between economic sectors have generated numbers of studies based on this methodology. These underline the positive effect of trade liberalization due to efficiency gains. Yet, a growing concern about the impacts of trade liberalization in developing countries, especially on poverty, has arisen. The consequences of various liberalization scenarios are now under scrutiny from the view point of equity within these countries (Hertel et al., 2002).

The new round of negotiations has been called the development round, , in the hope, among other reasons, that trade liberalization will help in fighting poverty. However, a particular bottleneck may arise from price instability. The negative impacts of price instability on the poorest are well documented. As consumers, they often spend more than half of their expenditures on food, which makes them sensitive to any price increase. With price instability and risk averse producers, supply is reduced at mean price equivalent. Thus, price instability increases mean prices, harming the poor.

Indeed, since the Roosevelt era, in the 1930's, following this simple reasoning, governments have tried to isolate their markets from world food price fluctuations through trade policies. Recently, stabilization has been recommended to fight poverty, on the ground that risk limits producers' investments and prevents them--especially, the poorest--using more efficient technology (Timmer 2000). In this context, attempts have been made to include price instability and its impact on the poorest in trade liberalization analysis (Hertel et al., 2001). But how can such instability be 
accounted for in models which, by construction, assume that prices are perfectly known? The key underlying issue, here, is where instability comes from.

Most of the time, price instability is only considered as a consequence of external shocks like climatic disturbances. In such a case, as demonstrated by Bale and Lutz (1978) and evaluated by Tyers and Anderson (1992), removing trade barriers stabilizes world price, because of the "Law of large numbers": many independent small shocks in various directions cancel out when pooled in one large market. Thus, including price instability in the model should improve the pro-poor impacts of trade liberalization (Hertel et al., 2001).

However, random events may not possess the nice properties of "Gaussian" perturbations (Mandelbrot, 1971). Moreover, weather and other "small" random events are not the only sources of price instability. A part, at least, of price instability in commodity markets is due to market behavior itself. Such a situation arises with imperfect information ( Kindelberger, 1996; Chavas and Holt, 1991). Ezekiel (1938) stressed the importance of price expectations in the price formation process. He showed that markets may tend to fail if demand is rigid and supply elastic, with huge fluctuations, panics and crashes. Several later authors, in the tradition of business cycle analysis, have shown that endogenous price fluctuations may be generated by models including liquidity constraint, risk and relatively rigid demand curves (Boussard, 1996; Day, 1999; Rosser, 2000).

When the source of fluctuations are non-Gaussian random events, or deterministic chaotic disturbances, conclusions derived from standard insurance analysis are no longer valid. For that reason, Stiglitz (2000) reminds us that the market economy is subject to large fluctuations and that public regulations are required, as demonstrated by the recurrent currency crisis in the nineteennineties. In this paper, imperfect information and expectations are introduced into a standard CGE model that includes a rich and a poor household in each region. Results from two versions of the model (that is, the standard model, versus the model with imperfect information assumptions) are analyzed and compared. 


\section{Modifying the basic CGE}

Let us define the sets I for factors, $\mathrm{J}$ for commodities, $\mathrm{H}$ for institutions, $\mathrm{t}$ for time. Denote by: $\mathrm{F}_{\mathrm{j}}($. a production function, $\mathrm{U}_{\mathrm{ht}}($.$) the utility function of consumer \mathrm{h}$, and $\mathrm{G}($.$) the investment function$ which transforms inputs into factors - mainly capital, but manpower as well.

Call $\mathrm{y}_{\mathrm{jt}}$, the supply of commodity $\mathrm{j} ; \mathrm{z}_{\mathrm{hjt}}$ the final consumption of commodity $\mathrm{j}$ by consumer $\mathrm{h} ; \mathrm{x}_{\mathrm{ij}}$ the quantity of commodity or factor $\mathrm{i}$ used as input for commodity $\mathrm{j} ; \mathrm{v}_{\mathrm{kjt}}$ the demand of commodity $\mathrm{j}$ by consumer $\mathrm{k}$ for investment; $\mathrm{e}_{\mathrm{hi}}$, the quantity of factor I belonging to institution $\mathrm{k}$; $\pi_{\mathrm{jt}}$, the profit of industry $\mathrm{j} ; \mathrm{s}_{\mathrm{ht}}$ the savings by institution $\mathrm{h}$; and $\delta_{\mathrm{hi}}$ a depreciation rate. Prices are denoted by $\mathrm{p}_{\mathrm{jt}}$ for commodity, $\gamma_{\text {it }}$ for factors.

Reduced to a skeleton, a standard recursive CGE model can be described as follows:

$$
\mathrm{F}_{\mathrm{j}}\left(\ldots \mathrm{x}_{\mathrm{ijt} . .}\right)=\sum_{k} \mathrm{Z}_{\mathrm{kjt}}+\sum_{i \in I, J} \mathrm{x}_{\mathrm{jit}}+\sum_{h} \mathrm{v}_{\mathrm{hjt}}, \quad \mathrm{j} \in \mathrm{J} \quad \text { (supply equates demand) }
$$

$$
\pi_{\mathrm{jt}}=\mathrm{p}_{\mathrm{jt}} \mathrm{F}_{\mathrm{j}}\left(\ldots \mathrm{x}_{\mathrm{ij} . .}\right)-\sum_{i \in J} \mathrm{p}_{\mathrm{it}} \mathrm{x}_{\mathrm{ijt}}-\sum_{i \in I} \delta_{\mathrm{it}} \mathrm{x}_{\mathrm{ijt},} \quad \mathrm{j} \in \mathrm{J} ; \quad \text { (producer's utility) }
$$

$$
\sum_{j} \mathrm{x}_{\mathrm{ijt}}=\sum_{k} \mathrm{e}_{\mathrm{hit}} \quad \forall i \in \mathrm{I} \quad \text { (factor availability) }
$$

$$
\mathrm{u}_{\mathrm{kt}}=\mathrm{U}\left(\ldots \mathrm{z}_{\mathrm{hjt} t .}, \mathrm{sht}_{\mathrm{ht}}\right), \quad \mathrm{h} \in \mathrm{H} ; \quad \text { (consumer's utility) }
$$

$$
\sum_{j} \mathrm{p}_{\mathrm{jt}} \mathrm{Z}_{\mathrm{hjt}}=\sum_{i \in I} \mathrm{~s}_{\mathrm{k}}+\gamma_{\mathrm{it}} \mathrm{e}_{\mathrm{iht}} \quad \mathrm{h} \in \mathrm{H} \quad \text { (consumer's budget constraint) }
$$

$$
\begin{array}{ll}
\mathrm{s}_{\mathrm{ht}}=\sum_{h} \sum_{j} \mathrm{p}_{\mathrm{jt}} \mathrm{v}_{\mathrm{hjt}} & \mathrm{h} \in \mathrm{H} \quad \text { (value for savings) } \\
\mathrm{e}_{\mathrm{hit}}=\mathrm{e}_{\mathrm{hit}-1}\left(1-\delta_{\mathrm{hi}}\right)+\mathrm{G}\left(. . \mathrm{v}_{\mathrm{hjt}} \ldots\right) & \mathrm{h} \in \mathrm{H}, \mathrm{i} \in \mathrm{I} \text { (recurrence equation) }
\end{array}
$$

The model is closed by writing the first-order conditions for producer's and consumer's optima, viz. the derivatives with respect to $\mathrm{x}_{\mathrm{ijt}}$ of equation (2) subject to (3), and the derivatives with respect to 
$\mathrm{Z}_{\mathrm{hjt}}$ and $\mathrm{s}_{\mathrm{ht}}$ of equation (4) subject to (5). Here, the only intertemporal equation is (9), which, applied to capital, is the basic dynamic equation.

\subsection{Decision lags, expectations and risk}

In order to include imperfect information, first, a lag is introduced between the production and the consumption decisions. Equation (1) must be rewritten as:

$$
\mathrm{F}_{\mathrm{j}}\left(\ldots \mathrm{x}_{\mathrm{ijt}-1 . .)}\right) \sum_{k} \mathrm{z}_{\mathrm{kjt}}+\sum_{i \in I, J} \mathrm{x}_{\mathrm{jit}-1}+\sum_{h} \mathrm{v}_{\mathrm{hjt}}, \quad \mathrm{j} \in \mathrm{J}
$$

Thus, the market equilibrium occurs between last year (given) production, and current consumption, meaning that production decisions are not based on equilibrium but on expected prices. Equation (2) is modified accordingly:

$$
\hat{\pi}_{\mathrm{jt}}=\hat{\mathrm{p}}_{\mathrm{jt}} \mathrm{F}_{\mathrm{j}}\left(\ldots \mathrm{x}_{\mathrm{ij} . . .}\right)-\sum_{i \in J} \mathrm{p}_{\mathrm{it}} \mathrm{x}_{\mathrm{ijt}}-\sum_{i \in I} \delta_{\mathrm{it}} \mathrm{x}_{\mathrm{ijt}} \quad \mathrm{j} \forall \in \mathrm{J},
$$

$\hat{\mathrm{p}}_{\mathrm{jt}}$ being the expected price. Many difficulties follow because:

i- $\quad$ an expectation function $\mathrm{E}_{\mathrm{m}}($.$) must be defined to determine \hat{\mathrm{p}}_{\mathrm{jt}}$.

ii- $\quad$ since $\hat{\mathrm{p}}_{\mathrm{jt}}$ itself is not known with certainty, a price risk exists, and must be accounted for in the producer decision model.

iii- $\quad$ as a consequence, not only the expected mean price $\hat{\mathrm{p}}_{\mathrm{jt}}$ but also the associated expected variance $\hat{\sigma}_{j t}^{2}$ (taken as a measure of volatility) must be determined, because, in pure decision theory, a prospect must be defined by the whole set of moments of the corresponding probability function. Here, we admit that only the first two moments, mean and variance, are sufficient.

A large number of expectation formulae have been tried. For most of the results presented here, as in Boussard (1996), $\hat{\mathrm{p}}_{\mathrm{jt}}=\tilde{p}$, while $\hat{\sigma}_{t}^{2}=\left(\hat{p}_{t-1}-p_{t-1}\right)^{2}$, mean price expectations are constant, and variance expectations are naïve. Of course, measuring a variance over only one observation 
might be debated. Yet, the formula certainly is an indication of the "surprise" associated with the new price observation. Other formulae have been tried, for instance naïve mean and variance expectations. This is a special case of a more general Nerlovian "adaptative" expectation scheme: $\hat{p}_{t}=\hat{p}_{t-1}+\beta\left(\hat{p}_{t-1}-p_{t-1}\right)$, and: $\hat{\sigma}_{t}^{2}=\hat{\sigma}_{t-1}^{2}+\lambda\left[\hat{\sigma}_{t-1}^{2}-\left(\hat{p}_{t-1}-p_{t-1}\right)^{2}\right]$ (Nerlove, 1979).

Another difficulty occurs because, since income is distributed before equilibrium is known, household incomes for year $t$ depend heavily on expectations for year $t+1$. This implies that firms may suffer losses or profit from gains. This kind of situation does occur in real life, although it is absent from standard models. For this reason, firms bear risks: this is the last and most important aspect of the model. Risk is modeled to play a key role in two different ways: in the producer's utility function (2b), and in the recurrence equation (7).

\subsection{The new producer's utility function}

In the producer's utility function, some sort of risk premium has to be introduced. Although there is a variety of possibilities, the simpler Markowitz utility function has been chosen. Thus, instead of (2b), we actually make use of (2c):

$$
\hat{\pi}_{j t}=\hat{\mathrm{p}}_{\mathrm{jt}} \mathrm{F}_{\mathrm{j}}\left(\ldots \mathrm{x}_{\mathrm{ij} . .}\right)-\sum_{i \in J} \mathrm{p}_{\mathrm{it}} \mathrm{x}_{\mathrm{ijt}}-\sum_{i \in I} \delta_{i t} \mathrm{x}_{\mathrm{ijt}}-2 \mathrm{~A}_{\mathrm{jt}} \hat{\sigma}_{j \mathrm{t}}^{2} \mathrm{~F}_{\mathrm{jt}}^{2}\left(\ldots \mathrm{x}_{\mathrm{ij}} . .\right)
$$

where $\hat{\sigma}_{j t}^{2}$ is the expected variance of $\mathrm{p}_{\mathrm{jt}}$, and $\mathrm{A}_{\mathrm{jt}}$ is a risk aversion coefficient. Here is the main reason for having defined an expectation function for variance.

The order of magnitude of $\mathrm{A}_{\mathrm{jt}}$ is important. This is an absolute risk aversion coefficient, the magnitude of which should therefore be commensurable with $1 / \mathrm{w}$, where $\mathrm{w}$ is the wealth of the decision-maker. Of course, the data used in our model in this respect are only general guesses.

Finally, the last term of equation (2c), $2 \mathrm{~A}_{\mathrm{jt}} \hat{\sigma}_{j t}^{2} \mathrm{~F}^{2}{ }_{\mathrm{jt}}\left(\ldots \mathrm{x}_{\mathrm{ij} . .}\right.$ ), is expected profit, which we distribute as the income from capital. 


\subsection{The recurrence equation}

Equation (2c) is not the only function for which risk matters, since for growth and accumulation, equation (7) and the function $G\left(. . v_{h j t} \ldots\right)$ are of utmost importance. In the first (standard) CGE version, function $\mathrm{G}$ is straightforward: changes in total labor force are driven by demography, while capital is easily shifted from one sector to another, so that this is "naturally" invested in the most productive places. However,, such assumptions are not very realistic; they imply that a nuclear power plant can be used to harvest grain, or that a bus driver can be employed immediately as a teacher in mathematics. Many models have been set up with sector-specific labor force and capital. However, neither capital nor labor are obviously caught in any sector for ever. Some flexibility must be added.

In the present model, simple assumptions have been made for labor: it shifts freely within specific sub-groups of sectors (agriculture, manufactures, services). Labor is immobile between these sub-groups, , except in some simulations where some migration has been allowed from one year to another (according to relative wages). In contrast, an original sub-model has been developed for capital. Old capital is fixed by sector and decays at a constant rate. But "new" capital owned by each institution is allocated between sectors according to a Markowitz(1970) mean/variance portfolio selection model. Let us define:

$\mathrm{k}_{\mathrm{jt}}$ : capital of branch $\mathrm{j}$, time $\mathrm{t}^{2}$

$\mathrm{S}_{\mathrm{t}}$ : total saving period $\mathrm{t}$

$\hat{\pi}_{j t}:$ expected profitability of capital in branch $\mathrm{j}$

$\hat{V}\left(\pi_{j t}\right):$ expected variance of $\pi_{j t}$

$\mathrm{A}_{\mathrm{k}}$ : risk aversion parameter 
$\mathrm{P}_{\mathrm{kjt}}$ : price of the capital good for branch $\mathrm{j}$

$\hat{P}_{k j t}:$ expected value of $\mathrm{P}_{\mathrm{kjt}}$

$\mathrm{I}_{\mathrm{jt}}$ : capital good bought for branch $\mathrm{j}$, time $\mathrm{t}$

Then, $\mathrm{I}_{\mathrm{jt}}$ is chosen by investors through the maximization of :

(8) $\sum_{j} \hat{\pi}_{j t} P_{k j t} I_{j t}-A_{k} \hat{V}\left(\pi_{j t}\right) \mathrm{I}_{\mathrm{jt}}^{2}$

subject to:

(9) $\sum_{j} P_{k j t} I_{j t} \leq S_{t}$

with a naïve expectation scheme :

(10) $\hat{\pi}_{j t}=\pi_{j t}$

(11) $\hat{P}_{k j t}=\mathrm{P}_{\mathrm{kjt}-1}$

(12) $\hat{V}\left(\pi_{j t}\right)=\left(\hat{\pi}_{j t-1}-\hat{\pi}_{j t-2}\right)^{2}$

In addition, since $\hat{P}_{k j t} \neq \mathrm{P}_{\mathrm{kjt}}$, some savings may last or be created in time t. These are then credited to or subtracted from savings in year $\mathrm{t}+1$.

The capital available for each branch $\mathrm{j}$ is updated in the recursive loop over time:

(13) $k j_{t+1}=k j_{t}\left(1-\delta_{j}\right)+I_{j t}$

Although exchange rate variability has not been taken into account, the model could easily be extended to cope with this important source of volatility.

\footnotetext{
${ }^{2}$ We also introduce the possibility of keeping savings as money, considered as an asset with null expected ability to rent, but without any risk of loss.
} 


\section{A world of perfect foresight versus uncertainty: models presentation}

The GTAP data base (version 4) has been used to represent the world through three ${ }_{\text {regions }}$ (Europe, United States, Rest of the world), five production factors (land, natural resources, skilled and unskilled labor, capital) and ten sectors, including five for agricultural production and one for agri-business ${ }^{4}$. Two types of households are considered, splitting the population around the income median, and defining a middle-low income and middle-high income group, in order to account for equity issues. Agricultural policy is represented by producer support estimates (PSE), as calculated by OECD. The Armington assumption of imperfect substitutes of products from different countries holds.

The production module represents physical flows of products, production and consumption behavior and has largely been taken from Burniaux and Van der Mensbrugge (1991). Production is described by embedded CES production functions. At the first level, aggregate added value and aggregate variable inputs are considered. These are disaggregated at the second level, where two other CES functions are used, one for the five production factors and another for inputs. Parameters are taken from the GTAP data base $\mathrm{e}^{5}$. Demand is a linear expenditure system, estimated by using GTAP income elasticities as well as consumption and price levels. Exchange rates are exogenous. Investment is determined by savings and foreign capital flows, calculated to balance the external trade. Government budget is balanced through public consumption adjustment. The two versions of the model are dynamic, using temporary equilibria. Because of uncertainty on agricultural prices, the expected profitability of agricultural activity, which determines resource allocations to the

\footnotetext{
${ }^{3}$ Another version of the same model splits the world into 12 regions using the same data base, allowing for a more detailed analysis of gains and losses across the world. The authors are currently working on updated versions of the model using GTAP version 5 and a new sectoral and spatial dissagregation

${ }^{4}$ Rice, Other Grains (wheat, other cereal grains), Other crops( Vegetables-fruits-nuts, oil seeds, sugar cane, sugar beet, plant-based fibers, others crops), Livestock (Bovine cattle-sheep-goats-horses, other animal products, raw milk, wool, silk worm cocoons, fishing), Forestry, Agri-business (9 GTAP sectors), Wood products, Other industries (15 GTAP sectors),Services (4 GTAP sectors),Energy, resources (7 GTAP sectors)

${ }^{5}$ Detailed equations of the model can be found in Boussard et al. (2002).
} 
various agricultural activities, may differ from the real measures, calculated one year later. Therefore, at least one production factor has returns distributed with the same lag, to allow the adjustment between expected and real results. Capital returns are calculated ex-post, in order to allow this adjustment.

\section{Results : welfare gains for the poor vanish with imperfect information}

From a computational point of view, a difficulty with the version two specifications is that the model did not converge in every situation but sometimes ran over a large number of "years" (we had results over 60 years), and sometimes failed to find a feasible solution after two years. The nature and parameter values of the expectation terms seemed to be important here, although it was difficult to discover generalities on the number of observations specific versions of the model could generate. This is not surprising in view of analytical results of Boussard (1996), showing the "fractal" nature of the parameter set within which a simple one commodity "risky cobweb" model converges to a chaotic attractor or an equilibrium point. Since our interest is the long run properties of this kind of model, we present here only some of the longest series we estimated. This protocol favours the most liberalization-oriented results, since liberalization is surely unsustainable if it leads to collapse. The prevalence of short-lived simulations might possibly explain the feature that, historically, no agricultural policy has lasted without change for more than a few years. Almost every time a policy change is observed, it is deemed necessary because "the present policy is unsustainable". Since the model assumes "continuation of the present policy" for dozens of years, it should not be surprising that this leads to inconsistencies. However, there are other explanations, and it is most likely that lags and the Markowitz's investment sub-model make the whole system numerically more unstable than in a standard model, with optimization starting points more remote from equilibrium than usual. Undoubtedly, to some extent this weakens our conclusions. However, we view these to be much stronger than those from standard models, which do not recognize the problem on which we focus. 
Some results are presented in figures 1 to 4 , displaying GDP variations due to trade liberalization over the simulation period (45 years) in the two versions of the model, the "standard" general equilibrium model without lags, and the model with imperfect information, described above In figure 1, the usual results of welfare gains associated with world trade liberalization in a world of perfect information are presented. Welfare gains increase over time, according to the depreciation and investment rates as well as labour migration across sectors, allowing production factors to be allocated in a more efficient way. As expected, agricultural trade liberalization is highly beneficial to most participants. It is particularly beneficial to the rest of the world, confirming the positive impact, at least at the aggregated level, of trade liberalization on poverty alleviation. As underlined by Anderson (2002) "fortuitously, that too is in the economic interests of rural poor countries". This result is confirmed by income analysis (figure 3): the poor from the Rest of the World are the winners of the game.

\section{(Introduce here figures 1 and 2)}

Figures 2 and 4 show results obtained from the modified model, including short term rigidity of agricultural supply, risk averse behavior and imperfect information. Results are typically unstable, at the aggregate level (GDP) as well as at the household incomes level. Periods of gains

succeed losses year after year. Overall, aggregate results for the whole simulation period are negative for all players. Thus, gains from liberalization are small, but significant, when market failures are neglected; they are obviously also present when it is not, but, in that case, the social cost of market failures is greater than the benefits derived from a more efficient factor usage at world level.

\section{(Introduce here Figures 3 and 4)}


Figures 1 to 4 were obtained from a three country, 17 sector model. The same basic model was also run, with various GTAP bases and sectoral disaggregations, for 13 and 15 regions.. The key behavioural parameters (demand elasticities for rich and poor, risk aversion, expectation schemes) were varied, as were policies (ranging from total liberalization to only suppressing production quotas in Europe). Although some details changed from one run to another, the general patterns shown in the figures were unchanged, at least when runs lasted for sufficiently long time periods to allow comparisons.

Since the model is complex, there are many reasons for such results. Nonetheless, there is a key mechanism at work: because of uncertainty, producers reduce supply. Hence, on average, prices rise. But high food prices are more detrimental for the poor than for the rich. In addition, rich farmers can better sustain risk and temporary low prices, as well as seize any potential profit opportunity, while poor farmers rarely benefit from temporary high prices. The mechanism is present everywhere, but works differently in different regions and is more easily seen in poorer regions, say in Sub-Saharan Africa, than in Europe (where the food industry plays a larger role and dampens retail price changes).. Figure 5 illustrates meat industry price fluctuations in the case of North Africa and the Middle East.

\section{(Introduce here figure 5)}

An important point is the fact that the fluctuations presented here have nothing to do with "climatic uncertainty" and that nothing is random in the model. In this model, uncertainty is purely endogenous and market generated. Thus widening markets is a poor remedy: by linking national markets together, fluctuations are synchronized and accentuated, but not damped down.』

\footnotetext{
${ }^{6}$ This is the reason to present results over 50 years, to obtain a general long run picture of the impact of trade liberalization on the world agricultural system.. This type of simulation model helps to explore possible futures and is not designed for shorter-term forecasting.

${ }^{7}$ The relationship between climate and agricultural markets is far from clear: while the impact of a climatic accident over any individual farmer is obvious, to perturb markets requires a sufficiently large area to be affected at the same time. Now, it turns out that, contrary to a very common creed, many climatic accidents affect only relatively small
} 
Nonetheless, the model is still much too "smooth" to take account of reality completely. As noted above, there is no market for money and no exchange rates. In addition, as also noted, labor markets are simply represented. More complex representations in alternative versions of this model are possible, however for reasons noted above, these were computational problematic, leading to failure of the model to run for more than a few periods. Work is in progress to assess whether this results from the optimization algorithm or has an economic explanation. I It should however be recognized that, a model is always an imperfect representation of the real world. Incorporating the problems of the world does have limits but is surely more credible than standard models, which simply deny the existence of the problem, and consequences, of imperfect information.

\section{Conclusions}

In this paper, two different versions of a world CGE model, one with classical perfect foresight, the other with imperfect information, are used to evaluate the impact of trade liberalization on growth and poverty. For each version, the results of a "free-trade" simulation are compared with the baseline scenario. The main finding is that the global gains associated with trade liberalization are removed when imperfect information assumptions are introduced in the model. As underlined by Stiglitz (1998), imperfect information appears as a constraint preventing the economy to reach the optimum. Recent economic crises have forced both academic economists and policymakers to question some of their most basic assumptions about the appropriate design of capital liberalization (Bagwati, 1998; Stiglitz, 2000). As underlined by Duncan (1997, page 442), "Research is needed on the question of the social value of reducing price uncertainty (...)". This research should include the impact of risks on producers' behavior.

areas. Even when the area is large, the effects of the shock are often like a panther skin, with many disaster spots bordered by "normal" conditions. It may explain why climate is certainly not the only explanation of agricultural markets instability, as shown for instance by Roll(1984) in the case of the orange juice from Florida. Potentially fruitful researches could be envisaged in this field. 
Price instability in particular remains a major issue: will price instability in agricultural markets be removed by trade liberalization or not? If price instability comes from exogenous, normally distributed shocks, it will be largely smoothed by globalization and may then be neglected. It is this line of reasoning which has been followed by global trade analysts till now. In contrast, if price instability is generated by market functioning due to imperfect information, risk averse behavior and liquidity constraints, then price instability would remain after trade liberalization and may seriously affect trade liberalization gains, as shown in this paper. As also found by Timmer (2000), for specific commodities in specific contexts, there may be social benefits from the reduction of price uncertainty.. 


\section{References}

Anderson K., 2002. Agriculture, Developing Countries and the WTO. In: Ingco M.D., Winters L.A. (eds), Millenium Round in Agriculture and the New trade Agenda From a Development Perspective, Cambridge University Press, Cambridge.

Bhagwati J., 1998. The Capital Myth. Foreign Affairs, May/June, 7-12.

Bale M., Lutz E. 1981. The effect of Trade Intervention on International Price Instability. Amer. J. Agr. Econ, 61 (3), 512-516.

Boussard J.M., Gerard F., Piketty MG., Christensen AK., Fallot A., Voituriez T, 2002. Modèle macro-économique à dominante agricole pour l'analyse de l'impact du changement climatique et des effets des politiques en terme d'efficacité et d'équité. Rapport final, GICC, CIRAD-AMIS, Ministère Français de l'Environnement, Jardin Tropical de Paris.

Boussard J.M., 1996. When risk generates chaos. Journal of Economic Behaviour and Organization, 29 (96/05), 433446.

Burniaux J-M., Van den Mensbrugghe, 1991. Trade policy in a global context: technical specification of the Rural/Urban - North/South applied general equilibrium model. OECD Development Center Technical, Working paper $\mathrm{n}^{\circ} 48$, Paris.

Chavas J.-P., Holt M.T., 1991. On Nonlinear Dynamics : The Case of the Pork Cycle. American Journal of Agricultural Economics , 73 (August), 819-828.

Day, R.H., 1963. Recursive programming and production response. North Holland, Amsterdam.

Day R.H., 1999. Complex Economic Dynamic volume II : An introduction to Macroeconomic Dynamics,. The MIT Press, Cambridge.

Duncan R., 1997. The world food Markets : commodity risk management policy. The Australian Journal of Agriculture and Resource economics, 41 (3), 429-443.

Ezekiel M.,1938. The Cobweb Theorem. Quaterly Journal of Economics, 53, 225-280.

Hertel T.W., 1997. Global Trade Analysis. Cambridge University press, Cambridge.

Hertel T.W., Anderson K., François J.F., Martin W., 1999. Agriculture and Non-agricultural Liberalization in the Millenium Round. Paper presented at the Global Conference on Agriculture and the new trade agenda in the WTO 2000 Negotiations (WTO,Geneva, 1-2 October).

Hertel T.W., Martin W., 2000. Liberalising Agriculture and Manufactures in a Millenium Round : Implications for developping countries. The World Economy, 23 (4), 455-469.

Hertel T.W, Preckel P.V., Reimer J.J., 2001. Trade Policy, stapple food price variability, and the vulnerability of low income households. Paper presented at the Fourth Annual Conference on Global Economic Analysis (Purdue, June 2729)

Hertel T.W, Preckel P.V., Cranfield J., Ivanic M., 2002. Poverty Impact of multilateral Trade liberalization. Paper presented at the Fifth Annual Conference on Global Economic Analysis, (Taipei June 2003).

Markowitz, 1970. Portfolio analysis : Efficient diversification of investments. Yale university press, Yale.

Mandelbrot B., 1971. When can Price be Arbitraged Efficiently? A Limit to the Validity of the Random Walk and Martingale Models. Review of Economics and Statistics, 55 (3), 225-236.

Nerlove M. , 1979.. The dynamics of Agricultural supply: retrospect and prospect. Amer. J. Agr. Econ. 61, 874-888.

Roll, R., 1984. Orange juice and weather. American Economic Review, Dec. 1984, 861-879. 
Rosser, J.B., 2000. Between Cambridge and Vienna : The risky business of new Austrian business cycle theory. Mimeo, James Madison University, Harrisonburg ( Va)

Stiglitz J.E., 2000. Capital Market Liberalization, Economic Growth, and Instability. World Development, 28 (6 ), 1075-1086.

Stiglitz J.E., 1998. Knowledge for development / Economic Science, Economic Policy, and Economic advice. Paper prepared for the Annual World Bank Conference on Development Economics, April 20-21, Waschigton DC

Timmer P., 2000. The macro dimensions of food security: economic growth, equitable distribution, and food price stability. Food Policy, 25, 283-295.

Tyer R., Anderson K., 1992. Disarray in World Food Markets : A Quantitative Assessment. Cambridge University Press, Cambridge. 
Figure 1 : Total liberalization induced changes in GDP according to the standard model

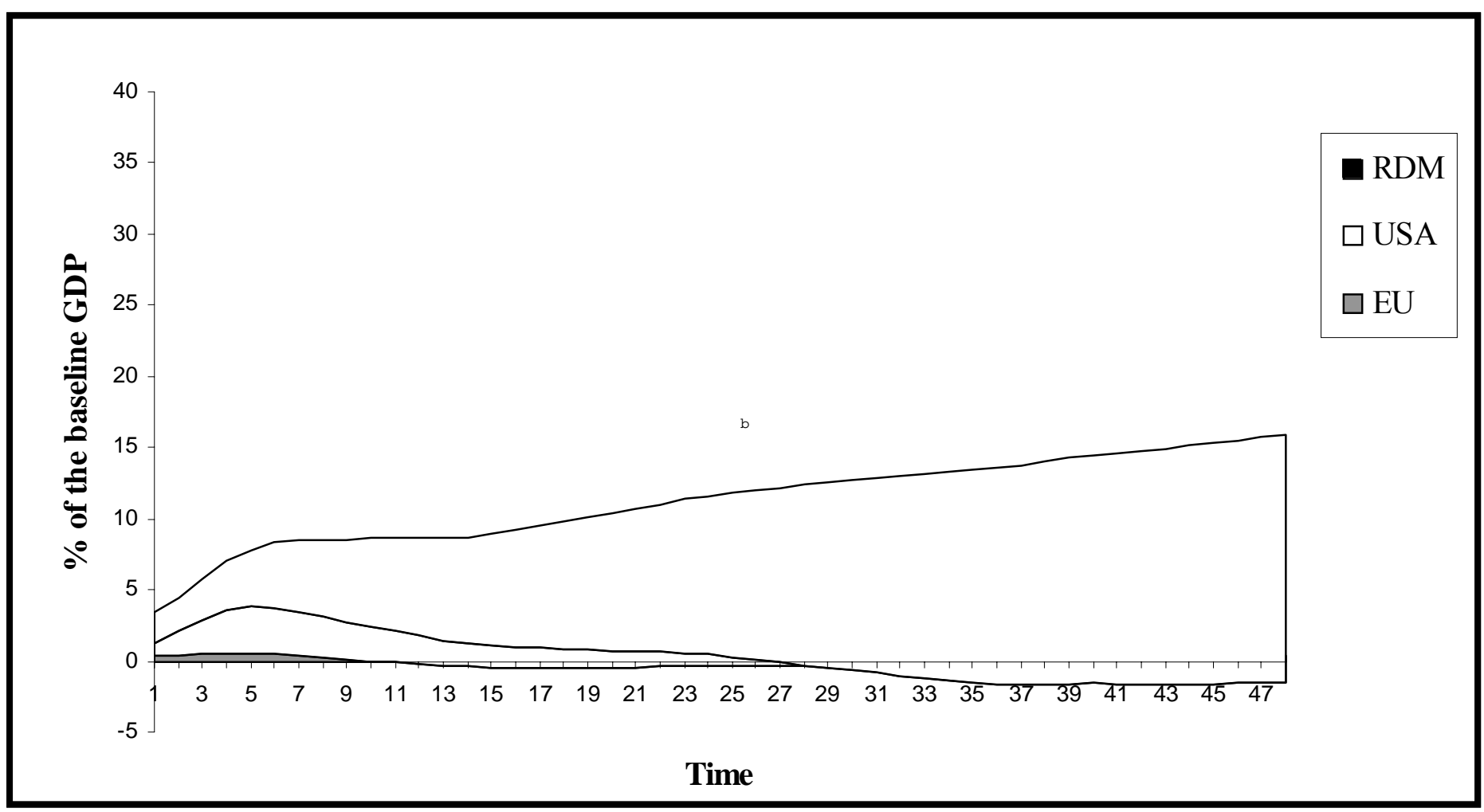


Figure 2 : Change in GDP from total liberalization according to the model with imperfect information and risk

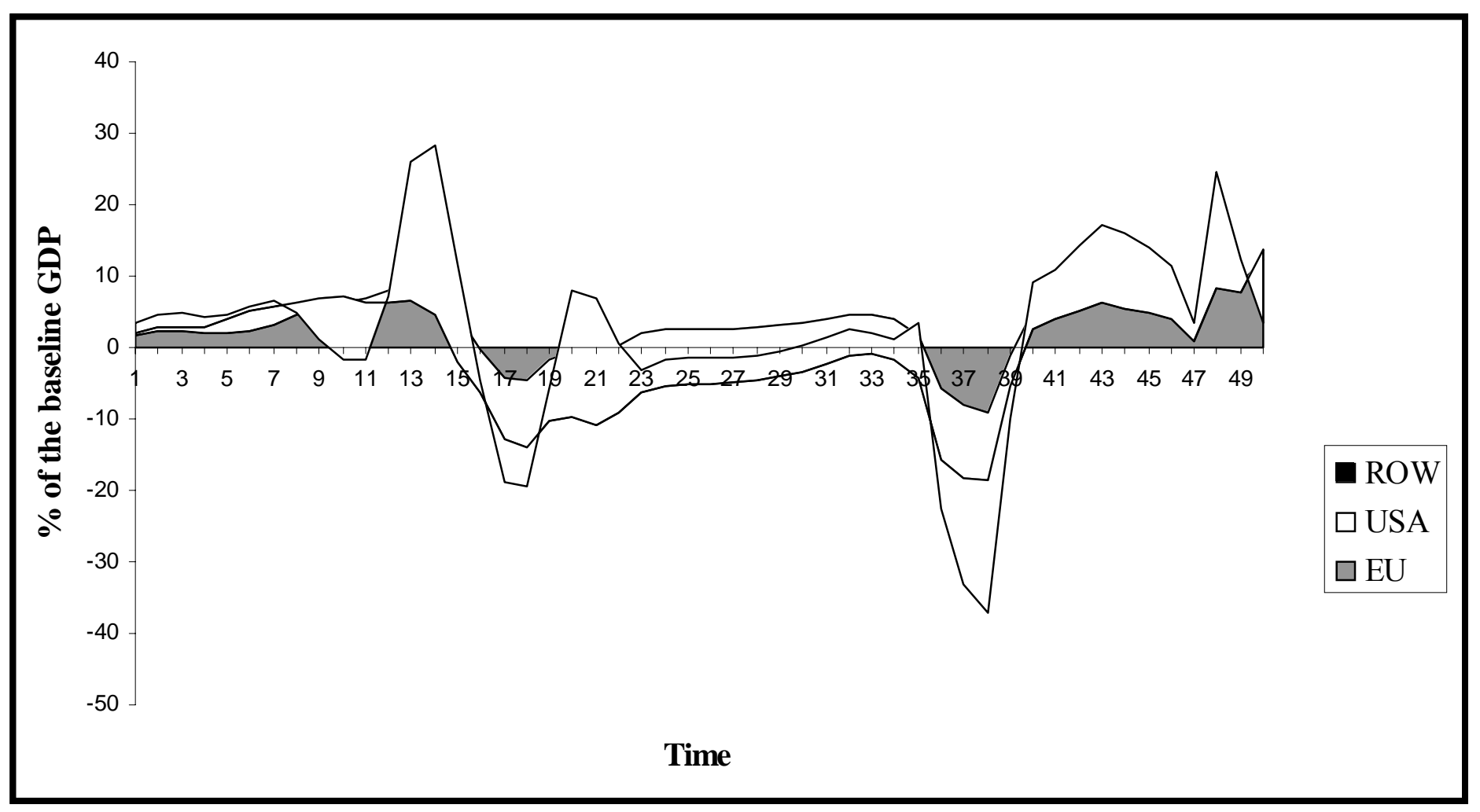


Figure 3 : Changes in housefiold income from total liberalization according to the standard model

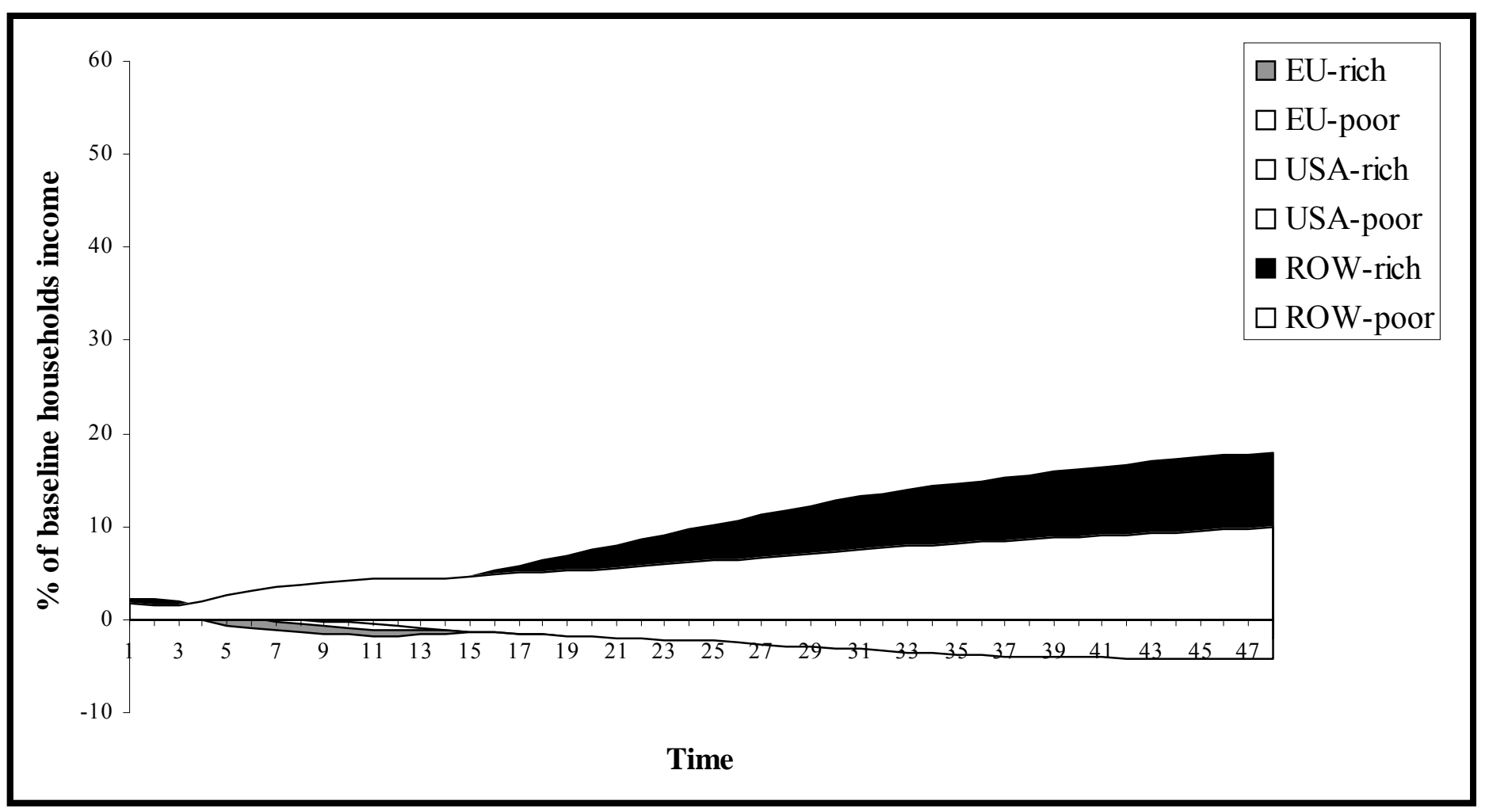


Figure 4 : Liberalisation induced change in household income according to the model with imperfect information and risk

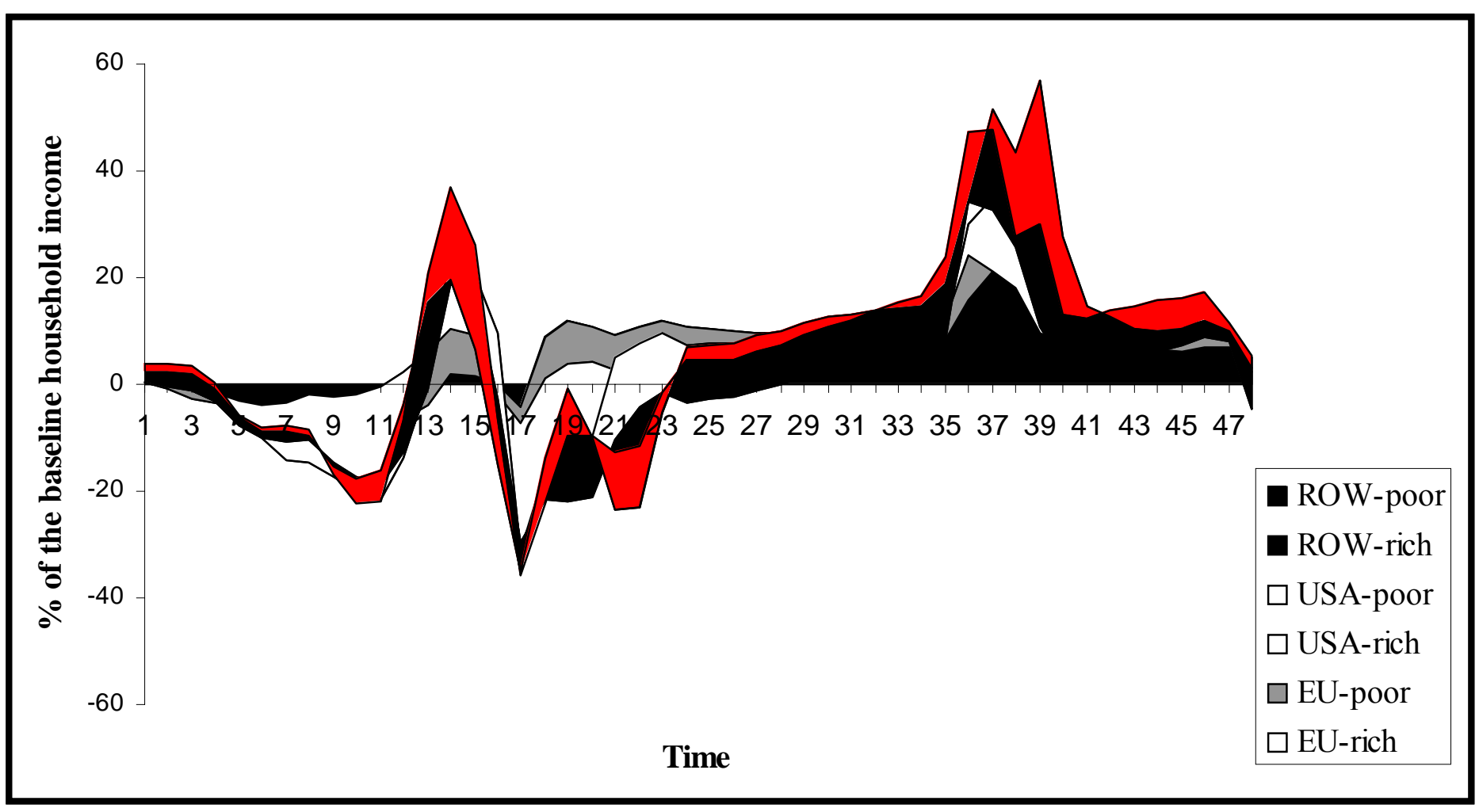


Figure 5 : Retail price of meat with and without liberalization ( "Middle East - North Africa" Region ) "Imperfect markets", 15 regions, 17 commodities, "no migration" model

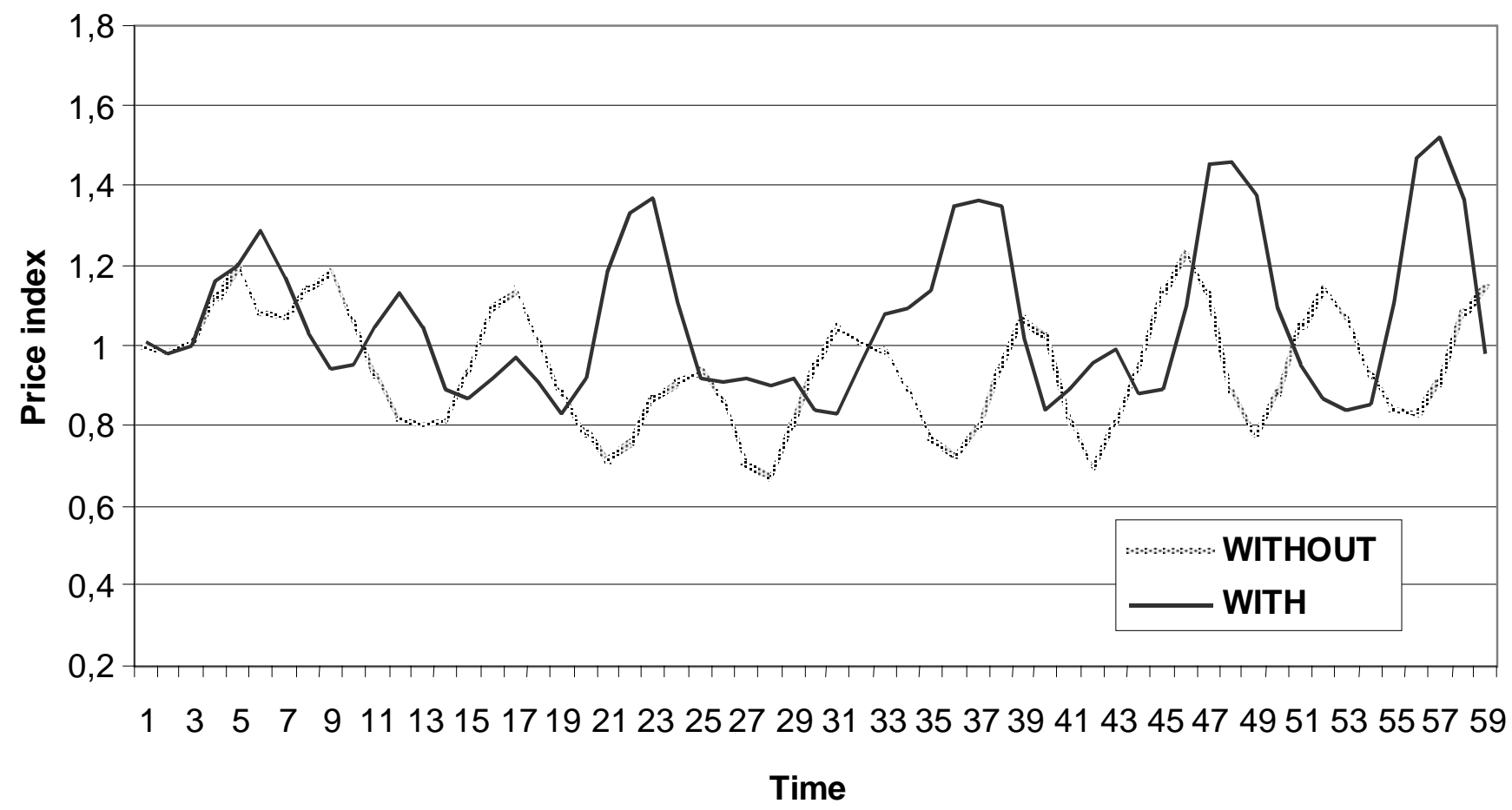

